\title{
Prevalence of Cholelithiasis in Patients with Type 2 Diabetes and Obesity in a Basic Family Health Centre in Irecê, Northeastern Brazil
}

\author{
Sarah Virgínia Dantas Guimarães ${ }^{1 *}$, Heldernilson Lopes Eugênio Gomes, \\ Claudio Galindo de Oliveira1, Marcus Fabiano Santana Rocha Chiacchio', \\ Fabricio Miranda Souza1, Daniel Souza Oliveira ${ }^{1}$, Renata Lima de Cerqueira1, \\ Jurandir José Cerqueira Dantas Junior ${ }^{1}$, Denise Rosso Tenório Wanderley Rocha², \\ Alberto Krayyem Arbex ${ }^{2,3}$

\footnotetext{
${ }^{1}$ Postgraduate Study Programme in Endocrinology, IPEMED Medical School (IPEMED), Bahia, Brazil

${ }^{2}$ Division of Endocrinology, IPEMED Medical School, Salvador-Bahia, Brazil

${ }^{3}$ Visiting Scientist of the Harvard T. H. Chan School of Public Health, Harvard University, Boston, USA

Email: "sarinha_vdg@hotmail.com
}

Received 13 December 2015; accepted 16 January 2016; published 19 January 2016

Copyright (C) 2016 by authors and Scientific Research Publishing Inc.

This work is licensed under the Creative Commons Attribution International License (CC BY).

http://creativecommons.org/licenses/by/4.0/

\section{(c) (i) Open Access}

\begin{abstract}
Cholelithiasis is a common disease in the general population. One of its risk factors is the type 2 diabetes mellitus, related to metabolic abnormalities associated to overweight, obesity, insulin resistance, hypertriglyceridemia and dietary habits. The main risk factors to cholelithiasis are genetic susceptibility, ileum resection, diabetes mellitus, obesity, hemolytic anemia, age, estrogens and cirrhosis. This study aims to make a correlation between diabetes mellitus and obesity versus prevalence of cholelithiasis in these patients.
\end{abstract}

Keywords

Diabetes Mellitus, Obesity, Prevalence and Cholelithiasis

\section{Introduction}

Acalculous gallbladder disease is a Public Health problem with social and economic implications that affect the "Corresponding author.

How to cite this paper: Guimaraes, S.V.D., et al. (2016) Prevalence of Cholelithiasis in Patients with Type 2 Diabetes Mellitus and Obesity in a Basic Family Health Centre. Open Journal of Endocrine and Metabolic Diseases, 6, 38-42. 
Brazilian health care system. Its distribution is universal, varying according to ethnic, hereditary and lifestyle factors [1].

It is estimated that $7 \%$ to $10 \%$ of the world's population are cholelithiasis carriers. In Brazil, the prevalence in necropsy studies in individuals over 20 years old varied from 9.1\% to 19.4\% [1] [2].

The cholelithiasis affects predominantly multiparous and obese women, doubling its incidence with the use of contraceptives and estrogen in the postmenopausal stage [3]. Its occurrence increases with age [2]-[5]; and parity [6].

One of its risk factors is the type 2 diabetes mellitus and it is related to metabolic abnormalities associated with overweight, obesity, insulin resistance, dyslipidemia and dietary habits [1] [7].

Obesity, overweight and rapid weight loss increases the risk of cholelithiasis [8], doubling its incidence in patients weighing $20 \%$ above the ideal [1].

During an assessment carried out in a Basic Family Health Centre, it was perceived that several diabetic and obese patients complained about abdominal pain and stomach discomfort related to Cholelithiasis and with this study, it is worth mentioning the prevalence of this pathology in patients with type 2 diabetes and obesity.

The patients of this study were seen at a Basic Family Health Centre in Irece-BA to perform glycemic control, periodic ambulatory care and dyspeptic symptoms and abdominal pain examination. This research covered the period between January and December of 2014 and a total of forty patients with previous diagnosis of type 2 diabetes mellitus, and thirty patients with various stages of obesity were assessed.

\section{Frequency of Cholelithiasis}

Its frequency varies according to the population studied either retrospectively, by autopsies and cholecystectomy rates, as prospectively via abdominal ultrasound [1] [9]. An estimated $7 \%$ to $10 \%$ of the world population is a cholelithiasis carrier [2]. Its prevalence is lower in African countries when compared to the United States and Europe [3]. In the United States, the estimated prevalence is $10 \%$ to $15 \%$, with one million new diagnosed cases per year resulting in 600,000 annual surgical interventions [3].

In Argentina, the overall prevalence is $20.5 \%, 23.8 \%$ of women and $15.5 \%$ of men and it is related, with both genders, to age and BMI [10].

In northern Italy, in the city of Sirmione, a population-based study with abdominal ultrasound in 4720 people was conducted and the occurrence of cholelithiasis was $6.7 \%$ in men and $14.6 \%$ in women [6].

In Brazil, a survey conducted by ultrasound, the prevalence reached $14.8 \%$ of those aged over 20 years old [3]. In Campinas, studying 2355 autopsies, a prevalence of $10.3 \%$ was found [4]. In the city of São Paulo, the autopsy study in patients older than 20 years of age, prevalence reached $14.7 \%$ and $26.4 \%$ in male and female genders, respectively [5].

\section{Pathophysiology of Cholelithiasis}

The formation of gallstones, in the gallbladder, is due to changes in the regulation of secretion of the main organic compounds of the bile with an absolute hypersecretion of biliary cholesterol and relative hypersecretion of bile acids, unbalancing the ratio and equilibrium of cholesterol/bile salts and lecithin, resulting in a lithogenic bile [2].

The increase in the cholesterol concentration in the cytoplasmic vesicles forms multilaminar particles, making room for crystal formation that clusters into solid form [2].

There are studies that establish a direct relationship between the high production of cholesterol by the liver associated with the metabolic syndrome and insulin resistance. Genetic, environmental and lifestyle factors provide increase of cholesterol and metabolic syndrome. Insulin resistance, on the other hand, is acknowledged as a main component in the biliary lithogenesis, which is now regarded as a manifestation of the metabolic syndrome [2] [9] [11]. The gallbladder motility is a relevant factor in the genesis of calculi, on this account the biliary stasis triggers mucin accumulation. This interferes the mechanism of gallbladder emptying, increasing the unconjugated products of the bilirubin, which, being slightly soluble may precipitate in the presence of calcium [2]-[11].

\section{Prevalence and Pathogenesis of the Diabetes Mellitus and Association with Obesity and Metabolic Syndrome}

Diabetes mellitus (DM) represents a group of metabolic diseases with various etiologies, characterized by hy- 
perglycaemia that results from impaired insulin secretion by the beta cells, peripheral resistance to insulin action or both. The two main etiologies are type 2 diabetes mellitus (T2DM) and T1DM, which corresponds to 5\% to $10 \%$ of cases. The chronic hyperglycaemia in diabetes is often associated with damage, dysfunction and failure of several organs, mainly eyes, kidneys, heart and blood vessels [12].

According to estimates of the International Diabetes Federation there are about 285 million diabetics in the world (6.4\% of the adult population) and that number will rise to approximately 440 million by 2030 [13]. This increase in the prevalence of DM is due to people longevity associated with an increased consumption of saturated fat, sedentary lifestyle and therefore obesity [14]. Approximately $70 \%$ to $90 \%$ of patients with T2DM also have metabolic syndrome, characterized by a group of factors that imply a high cardiovascular risk (dyslipidemia, abdominal obesity, insulin resistance, altered glucose tolerance or diabetes and hypertension) [15].

The main pathophysiological mechanisms leading to hyperglycemia in T2DM are peripheral resistance to insulin action in adipocytes and mainly in skeletal muscle; impaired insulin secretion by the pancreas: increased hepatic glucose production, resultant of insulin resistance in the liver. However, other components play an important role in the pathogenesis of type 2 diabetes: the adipocyte (accelerated lipolysis), gastrointestinal tract (deficiency/incretin resistance), pancreatic alpha cells (hyperglucagonemia), kidney (increased reabsorption of glucose by the kidney tubules) and the brain (insulin resistance). As a group, these components consist of what has been recently called "ominous octet" [16].

The most relevant risk factors for the development of type 2 diabetes are associated with metabolic syndrome. Obesity is the most important one (especially the one with predominantly abdominal fat distribution). In general, the higher the waist circumference and body mass index, the greater the risk of T2DM. The incidence of T2DM is five times higher in patients with metabolic syndrome (MS), compared to a group of patients without the syndrome [16].

\section{Cholelithiasis in Diabetic Patient}

Experimental and epidemiologic studies support the concept that people with diabetes have a higher risk to cholelithiasis, although not universally accepted. Likewise, there is no consensus on what is the most appropriate course of action towards the diabetic patient with gallstones. The literature reports higher incidence of gallstone disease in diabetic patients, although this fact may be related to the dietary habits of people with diabetes, the common overweight in this condition or old age, rather than the diabetes itself. However, the autonomic neuropathy, when installed, could be responsible for lithiasic tendency in this group of patients [17].

One study looked at 566 cholecystectomies for acute cholecystitis, 123 of these patients were diabetic, 433 nondiabetic. The diabetic group showed morbidity (21\% vs. 9\%) and significantly higher mortality rates [13].

In a study of cases and controls with 72 emergency cholecystectomies, diabetic patients had more complications (38.9\%) than nondiabetics (20.8\%) did. Infection was the main cause, three times more frequent in diabetic patients. Validating these findings, a study with autopsies showed that although rare, severe complications and death from cholelithiasis were significantly more common in diabetic patients than in nondiabetics [18].

The susceptibility of infections in diabetic people should contribute to such complications, since high glucose concentration, hyperinsulinemia, dehydration, malnutrition and vascular disease lead to the disequilibrium of exacerbated host by phagocytosis default, chemotaxis and intracellular bactericidal activity [18].

\section{Pathogenesis of Cholelithiasis in Type 2 Diabetic Patients}

Although the increased risk of cholelithiasis is well documented among diabetic patients, pathogenic mechanisms are not yet so clear. A study indicated that patients with type 2 diabetes presented a supersaturation of interdigestive bile with low concentration of bile acids, whereas patients with type 1 diabetes mellitus and normal control showed no such changes. It is also well documented that there is a relationship between the state of hyperinsulinism, more often in patients with type 2 diabetes mellitus, with the increase of gallstones [19]. Furthermore, the risk of cholesterol stone formation and diabetes are due to a likely gallbladder hypomotility, mainly due to an underlying autonomic neuropathy—diabetic gastroparesis [17].

\section{Treatment}

The treatment aims surgical removal of the gallbladder initially performed by laparotomy. At the end of the 
twentieth century, it began to be performed using smaller accesses, such as minilaparotomy and then by laparoscopy, which is considered the gold standard access these days [7].

\section{Study Group and Outcomes}

Over 12 months, from January 2014 to December 2014, 70 records of patients with type 2 diabetes were evaluated in a clinic. From the patients evaluated, 26 of them were diagnosed with cholelithiasis (37.1\%) with an average of 50.5 years of age. The number of obese patients with biliary lithiasis was $35 \%$ when compared to noncarriers of cholelithiasis, and they were all diabetics. In a study, Ferreira et al., found, in a group of patients studied by him, that $9 \%$ had diabetes and of these patients, approximately $54 \%$ had gallstones, a number considered high for this group. Regarding age, Coelho et al. found an average of 59.9 years old [3] [17]. In the results found for patients with cholelithiasis, there was a predominance of women, similar to the study of Nakai et al., in which the frequency of cholelithiasis was $23.8 \%$ of women versus $15.5 \%$ of men; $14.6 \%$ women versus $6.7 \%$ men and $26.4 \%$ women versus $14.7 \%$ men, respectively [5].

\section{Conclusion}

Analysis of the data obtained in this study showed a prevalence of cholelithiasis of approximately $37 \%$ out of 70 patients with type 2 diabetes in a Basic Family Health Centre in Sao Francisco neighborhood in the city of Irece, Bahia. This high prevalence can be explained by the following hypotheses: bile of diabetic patients is more lithogenic since the supersaturation of cholesterol in bile is higher and the concentration of bile acids is lower. It leads to the formation of gallstones; and the gallbladder hypomotility of diabetics that, due to hyperglycemia, leads to autonomic neuropathy, stenosis of the arterioles and reduction of the smooth muscle sensitivity that facilitates the biliary stasis and therefore the formation of stones. Due to the high prevalence of cholelithiasis in patients with diabetes and obese patients supported in the literature [17] [20], it is questioned the utility, during primary health care, the application of abdominal ultrasonography in basic propaedeutic diabetic and obese patients in different degrees facilitates the possibility of cost reduction (treatment of complications) and decreases mortality in this group of patients.

\section{Acknowledgements}

Authors would like to thank IPEMED for encouraging scientific study in order to improve medical education in Brazil and abroad.

\section{References}

[1] Torres, O.J.M., Barbosa, E.S., Pantoja, P.B., Diniz, M.C.S., Silva, J.R.S., et al. (2005) Prevalência ultra-sonográfica de litíase biliar em pacientes ambulatoriais. Revista do Colégio Brasileiro de Cirurgiões, 32, 47-49. http://dx.doi.org/10.1590/S0100-69912005000100011

[2] Roesch-Dietlen, F., Pérez-Morales, A., Melo-Santisteban, G., Díaz-Blanco, F., Martínez-Fernández, S., Martínez, J.A. and Cid-Juárez, S. (2008) Frequency and Clinical, Biochemical and Histological Characteristics of Nonalcoholic Fatty Liver Disease in Patients with Gallstone Disease. Revista Cirugia y Cirurjanos, 76, 37-42.

[3] Coelho, J.C., Bonilha, R.G., Pitaki, S.A., Cordeiro, R.M., Salvalaggio, P.R., Bonin, E.A., Hahn, C.G., Soares, R.V. and Milcheski, D.A. (1999) Prevalence of Gallstones in a Brazilian Population. International Surgery, 84, 25-28.

[4] Mantovani, M., Leal, R.F. and Fontelles, M.J. (2001) Incidência de colelitíase em necropsias realizadas em hospital universitário no município de Campinas, SP. Revista do Colégio Brasileiro de Cirurgiões, 28, 259-263. http://dx.doi.org/10.1590/S0100-69912001000400005

[5] Nakaie, M., Bevilacqua, R.G., Birolini, D. and Oliveira, M.R. (1982) Incidência de colelitíase em autópsias no município de São Paulo. Revista Paulista De Medicina, 100, 11-15.

[6] Barbara, L., Sama, C., Morselli Labate, A.M., Taroni, F., Rusticali, A.G., Festi, D., Sapio, C., Roda, E., Banterle, C., Puci, A., Formentini, F., Colasanti, S. and Nardin, F. (1987) A Population Study on the Prevalence of Gallstone Disease: The Sirmione Study. Hepatology, 7, 913-917. http://dx.doi.org/10.1002/hep.1840070520

[7] Salim, M.T. and Citait, R. (2008) Complicações da cirurgia videolaparoscópica no tratamento de doenças da vesícula e vias biliares. Arquivos Brasileiros de Cirurgia Digestiva, 21, 153-157. http://dx.doi.org/10.1590/S0102-67202008000400001 
[8] Torgerson, J.S., Lindroos, A.K., Näslund, I. and Peltonen, M. (2003) Gallstones, Gallbladder Disease, and Pancreatitis: Cross-sectional and 2-Year Data from the Swedish Obese Subjects (SOS) and SOS Reference Studies. The American Journal of Gastroenterology, 98, 1032-1041.

[9] Lopes, A.C. (2009) Tratado de Clínica Médica. Vol. I., 2nd Edition, Roca, São Paulo.

[10] Brasca, A.P., Pezzotto, S.M., Berli, D., Villavicencio, R., Fay, O., Gianguzzo, M.P. and Poletto, L. (2000) Epidemiology of Gallstone Disease in Argentina: Prevalences in the General Population and European Descendants. Digestive Diseases and Sciences, 45, 2392-2398. http://dx.doi.org/10.1023/A:1005647226746

[11] Santos, J.S., Sankarankutty, A.K., Salgado Júnior, W., Kemp, R., Módena, J.L.P., Elias Jr., J. and Silva Jr., O.C. (2008) Colecistectomia: Aspectos técnicos e indicações para o tratamento da litíase biliar e das neoplasias. Medicina Ribeirão Preto, 41, 449-464. http://dx.doi.org/10.11606/issn.2176-7262.v41i4p449-464

[12] American Diabetes Association (ADA) (2012) Diagnosis and Classification of Diabetes Mellitus. Diabetes Care, 35, S64-S71. http://dx.doi.org/10.2337/dc12-s064

[13] Souza, L.J., Chalita, F.E.B., Reis, A.F.F., et al. (2003) Prevalência de diabetes mellitus e fatores de risco em Campos dos Goytacazes, RJ. Arquivos Brasileiros de Endocrinologia e Metabologia, 47, 69-74. http://dx.doi.org/10.1590/s0004-27302003000100011

[14] Vilar, L. (2013) Endocrinologia Clínica. 5th Edição. Guanabara Koogan, Rio de Janeiro.

[15] Laaksonen, D.E., Niskanen, L. and Lakka, H.M. (2004) Epidemiology and Treatment of the Metabolic Syndrome. Annals of Medicine, 36, 332-346. http://dx.doi.org/10.1080/07853890410031849

[16] Eckel, R.H., Grundy, S.M. and Zimmet, P.Z. (2005) The Metabolic Syndrome. The Lancet, 365, 1415-1428. http://dx.doi.org/10.1016/S0140-6736(05)66378-7

[17] Ferreira, A.C., Filho, F.M., Mauad, F.M., et al. (2004) Fatores de risco clínicos e ultrassonográficos relacionados à litíase vesicular assintomática em mulheres. Revista Radiologia Brasileira, 37, 77-82. http://dx.doi.org/10.1590/S0100-39842004000200004

[18] Trindade, M.R.M., Neubarth, E. and Catucci, B.J. (2004) Manejo da Colelitíase no paciente Diabetico na era Videolaparoscópica. Revista Brasileira de Videocirurgia, 2, 161-165.

[19] Mendez, S.N., et al. (2005) Metabolic Syndrome as a Risk Factor for Gallstone Disease. World Journal of Gastroenterology, 11, 1653-1657. http://www.ncbi.nlm.nih.gov/pubmed/15786544

[20] Antoniello, R.L., García, C., De Soto Ricci, G. and Ricci, M.M. (1999) Prevalencia de la litiasis biliar en la diabetes mellitus / Prevalence of biliary lithiasis in diabetes mellitus. Revista Médica Del Uruguay, 15, 49-56. 